\title{
The Effect of Enterprise Risk Management Implementation on the Value of Companies Listed on the Nairobi Stock Exchange
}

\author{
Nelson Waweru ${ }^{1}$ and Eric Kisaka ${ }^{2}$
}

\begin{abstract}
This study assesses the level of implementation of Enterprise Risk Management (ERM) in companies listed in the Nairobi Stock Exchange (NSE). The study also seeks to test the significance of factors affecting this level of ERM implementation and to investigate whether the level of ERM implementation has a positive effect to the value of companies as measured by Tobin's Q. Data was collected from a sample of 22 companies listed on the NSE for the periods ended December 2009.

The research findings show that most of the organizations sampled viewed ERM implementation as a strategic business initiative as compared to a compliance requirement. The study also finds that there is a significant relationship between the appointment of a Chief Risk Officer and the level of Enterprise Risk Management Implementation in companies. However, it does not find a significant relationship between the level of ERM implementation and the following variables; industry of operation, level of board independence, size of the firm, and growth rate of the firm. Consistent with prior research, this study also found a significant relationship between a company's level or Enterprise Risk Management implementation and the company's value. The results of this study show that an increase in the level of ERM implementation in companies had a positive contribution to the value of the companies.
\end{abstract}

${ }^{1}$ York University, Toronto, Canada.

e-mail: waweru@yorku.ca

${ }^{2}$ Strathmore University, Nairobi, Kenya.

e-mail: ekisaka@gmail.com

Article Info: Received: January 22, 2013. Revised : February 11, 2013.

Published online : May 1, 2013 
JEL classification numbers: G1, G3

Keywords: Enterprise Risk Management, Company Value, Nairobi Stock Exchange, Kenya

\section{Introduction}

In business, there is no way of avoiding risk without giving up the opportunity to gain profits. Therefore, to be competitive, companies must learn how to manage risk intelligently. This means identifying risks early, expecting the unexpected and knowing which risks are worth taking and which to avoid. The main objective of this study is to assess whether the level of ERM implementation in companies listed in the NSE causes an increase in the value of those companies and establish the significant factors that influence the level of ERM implementation in companies listed in the NSE.

In the past, companies have been using the "Traditional Risk Management" 3 concept to manage risk. However, this approach is limited in scope and application as noted by (Kleffner et al, 2003 and Hoyt et al, 2008). The "Traditional Risk Management" concept appears to be lacking in terms of total integration. This is because risk exposures are being managed in silos hence the incompleteness of such an approach, (Lam, 2000; Davenport \& Bradley, 2001; Barton, Shenkir \& Walker; 2002). As a result of these shortcomings, the gradual change from traditional risk management to an all-encompassing risk management concept, Enterprise Risk Management (ERM) ${ }^{4}$ has gained substantial acceptance in the recent years.

Kleffner et al (2003) define ERM as the management of operational and financial risks simultaneously in order to maximize the cost effectiveness of risk management within the constraints of the organization's tolerance for risk. Though this definition encompasses operational risks, it fails to appreciate that companies are exposed to other risks like strategic and reputational risks and also fails to identify who is responsible for risk management in organization. The definition also fails to show the linkage of risk management to the organization's objectives. COSO (2004) on the other hand defines ERM as "a process, effected by an entity's board of directors, management and other personnel, applied in strategy setting and across the enterprise, designed to identify potential events that may affect the entity, and manage risk to be within its risk appetite, to provide reasonable assurance regarding the achievement of entity objectives".

From the different definitions of ERM, the underlying principles of ERM seem to be an integrated approach to risk management across silos, backed by corporate risk philosophy or strategy with the aim of maximizing organization value (Kleffner et al, 2003; COSO, 2004; Beasley et al, 2005; Panning, 2006).

Though the implementation of risk management is gaining prominence globally,

\footnotetext{
${ }^{3}$ March and Shapira (1987) define traditional risk as simple variance. This concept focused more on financial risk management and viewed risk management as a special function rather than a part of decision making (Boyer et, al, 2005). In traditional risk management, risks are separately managed in silos and are centered on two risk management activities - Insurance and hedging (Hoyt et al 2008). In essence, this concept seems to focus more on safety and security rather than value creation (Hussin et al, 2008)

${ }^{4}$ ERM is synonymous with Integrated Risk Management (IRM) and Enterprise wide risk management (EWRM). For consistency we use the acronym ERM in this paper.
} 
(Economist Intelligence Unit, 2001; Kleffner et al, 2003; Liebenberg and Hoyt, 2003; Beasley et al, 2005), some studies undertaken have shown that the implementation of risk management practices does not have any value addition to companies (Sharpe, 1964; Lintner, 1965). These studies argue that in the absence of market inefficiencies, investors can undo any financial transaction undertaken by a firm thus the firm value is independent of the risk management strategy (Efficient market hypothesis). For example, the Modigliani and Miller (1958) theorem states that in perfect markets a company's capital structure which is an integral component of its risk management, is irrelevant to the company's value. Jin and Jorion (2005) also studied the hedging activities of 119 U.S. oil and gas producers from 1998-2001 and concluded that, while hedging, which is a common form of risk management, reduced the company's stock price sensitivity to oil and gas prices, it did not appear to increase the value of the firm. Other studies that concluded that risk management does not have a significant effect on the value of companies include; Nain (2004) and Lookman (2004).

However, contradicting this argument, Yow and Sherris (2008) argue that, in practice, market imperfections exist and informational asymmetries create frictional costs for the firm. They argue that risk management can add value to the company through different ways like reducing earnings, cashflow or stock price volatility. These studies have a limitation in measurement of the value of companies because, though a reduction of volatility increases predictability of returns from the firm, the reduction of volatility does not seem to have a direct correlation to the value of the firm.

In light of the contradictory arguments on the value proposition of ERM, and the need to justify the cost of implementing ERM in companies, this study seeks to investigate whether the implementation of risk management has a positive contribution to the company's value (using Tobin's $Q$ as a measure of firm value). The results of this study will contribute to a better understanding of the value proposition of ERM for corporate executives thus giving them a quantifiable business case through a cost benefit analysis of ERM implementation.

It will be noted that most of the research work quoted in this study focused on companies in developed countries with only a few in emerging markets. However, although the underlying principles in ERM generally apply to most companies and countries, there are some aspects of risk management that might be specific to emerging markets. These markets generate higher rates of return on capital markets than mature markets, are characterized by high rates of volatility and are more susceptible to external impact including regulatory and operational, (Fuss, 2002). Therefore, this research will also assess the significance of factors previously identified to possibly have influence on the level of implementation of Enterprise Risk Management but with a specific focus on emerging markets.

Therefore this study seeks to contribute to research by investigating the significance of factors that influence ERM implementation and whether the implementation of ERM results in the increase of the company's value. This research differs from previous research done because it is being undertaken in companies listed in a developing market that probably faces different market characteristics from those listed in developed markets (Fuss, 2002).

Using a sample of 22 companies, this study found a significant relationship between ERM adoption and the presence of a chief risk officer among the companies listed in the NSE. Furthermore the study found that firm value was significantly associated with the level of ERM adoption. The study contributes to a better understanding of the value proposition of 
ERM for corporate executives thus giving them a quantifiable business case. The study also highlight the significance of factors that lead to institutions being at different levels of implementation thus enable corporate executives to better make the decision on how to invest in ERM and on controlling the factors that would otherwise affect their level of implementation over time.

The remainder of this paper is organised as follows: The second section reviews the related literature and develops the hypotheses. The third section presents the research design. The findings are presented in section 4 while, followed by a discussions in section 5 and conclusions in section 6.

\section{Literature Review and Hypothesis Development}

\subsection{Prior studies}

In classical decision theory, risk is most commonly conceived as reflecting variation in the distribution of possible outcomes, their likelihoods, and their subjective values. Risk is measured either by nonlinearities in the revealed utility for money or by the variance of the probability distribution of possible gains and losses associated with a particular alternative (Pratt 1964). However, this definition of risk fails to factor in human judgment which could also have influence on the perception of whether something is a risk or not.

In a study of managerial perspective of risk and risk taking, March and Shapira (1987) finds that managers see risk in ways less precise and different from risk as it appears in decision theory. The study finds three differences between managers perception of risk and decision theory. It finds that management does not treat uncertainty about positive outcome as an important aspect of risk but rather associate risk with negative outcome. This means that positive variations from possible outcomes will not be considered as risks. Secondly, the study suggests that for managers, risk is not primarily a probability concept but rather defined risk in terms of amount of loss.

There are several theories that lend themselves to ERM. Some of these theories include stakeholder theory, contingency theory and decision theory. In his study of the effect of stakeholder theory on risk management, Aabo (2004) investigates the relationship between the objectives of companies and the risk management strategy that the companies employ. The study shows a distinct difference between the two groups of companies in relation to actual risk management decisions which in turn have an effect on whether the risk management decisions will have a value addition or value retention effect on the company. This study concludes that this difference in risk management behavior could not be explained by company characteristics normally identified in the literature as being decisive for the extent of hedging such as firm size, leverage, and export ratio. Rather, the study finds a unique relationship between the managerial focus on stakeholders taking a conservative risk management strategy (that focused more on value preservation) and managerial focus on shareholder taking a forward looking risk management strategy (that focused on value addition).

Other than that, the level of ERM implementation and the factors that affect this level thereof seem to follow contingency theory. This theory contends that there is no one best way of organizing and that an organizational style that is effective in some situations may not be successful in others (Fiedler, 1964). That is, optimal organization style is 
contingent upon various internal and external constraints. Four important ideas of Contingency Theory are: There is no universal or one best way to manage, the design of an organization and its subsystems must 'fit' with the environment, effective organizations not only have a proper 'fit' with the environment but also between its subsystems and the needs of an organization are better satisfied when it is properly designed and the management style is appropriate both to the tasks undertaken and the nature of the work group (Wade and Tomasevic, 2006).

According to Innes and Mitchell (1990), the specific circumstances influencing an organizations management accounting practices comprise a set of contingent variables which may include but are not limited to; the external environment, technology, organization structure and age of firm. Therefore, Contingency theory will also apply in this research because the level of ERM implementation in a company might be influenced by a set of contingent variables which include size, industry, auditors, growth rate, regulatory requirements, ownership structure and board independence among others. .

\subsection{Measuring ERM Implementation}

There is limited research on criteria to be used in assessing the implementation of ERM in institutions. Most of the criteria used has been developed by consulting firms such as Deloitte with their risk intelligence maturity model and Standard and Poor's with the criteria used for measuring the implementation of ERM to be used in rating insurance companies (Standard \& Poor's Ratings Direct, 2007).

When evaluating ERM capabilities, Standard \& Poor's (S\&P) primarily looks at how an insurer's management defines the company's loss tolerance and how it ensures that it keeps within that loss tolerance. S\&P focus on the degree to which the institution's management accounts for risk and return for risk taking in setting corporate direction and in strategic decision-making. The areas that S\&P looks at are:

Risk Management culture- S\&P examines whether the company has clearly articulated its risk tolerance.

Risk control- S\&P reviews summary descriptions of risk-control programs and examples of how the programs are executed.

Emerging risk management- S\&P looks for evidence that the company is managing emerging risks in anticipation of problem events. It also looks at how effective emerging risks management has been during and after adverse events.

Risk and economic capital models - S\&P looks for evidence that the insurance company: has appropriately developed risk capital amounts consistent with its risks and risk-management programs; has an update and validation process that produces a result consistent with the intent of the company and are produced on a schedule that will support usage in the company's Strategic Risk Management processes.

Strategic risk management - S\&P's analysis of SRM starts with understanding the risk profile of the insurer and getting management to explain the reasons for recent changes in the risk profile and the changes it expects to make in future.

However, other than this criterion being customized specifically for the insurance industry, S\&P also points out that the criteria is primarily subjective (Standard \& Poor's Ratings Direct, 2007) thus introduces the limitation of human bias in judgment and is not customized to measure the level of ERM implementation across different industries. On the other hand, Liebenberg and Hoyt (2003) acknowledge the fact that "an obstacle to empirical ERM related research is the difficulty in identifying firms that are indeed 
engaging in ERM. Their study therefore uses the appointment of a Chief Risk officer (CRO) as a signal of ERM implementation. The key limitation of this method is that it does not seem to take into account the fact that there are companies where ERM implementation is championed by the Chief Audit Executive (CAE) thus some companies may be judged as not having implemented ERM when in actual fact they have. This method also does not consider the transitory nature of ERM implementation thus only assumes two states, that is ERM is fully implemented or not implemented at all.

As a consequence of the above limitations, Beasley et al (2005), measures ERM using and ordinal dependent variable, (ERM STAGE) which reflects a value ranging from 1 to 5 where; 5 = Complete ERM in place, $4=$ Partial ERM in place, $3=$ planning to implement ERM, 2 = Investigating ERM but no decision made and 1 = no plans exist to implement ERM. This data was collected through an online survey with Chief Audit Executives who are members of the institute of internal auditors being the main respondents. This method of measurement has also been used by the Economist Intelligence Unit (2009) study of the new era for risk management in financial services. Beasley et al (2005) found that $50 \%$ of the entities in the sample had either partially or completely implemented ERM, while $35 \%$ had not made a decision to implement ERM or had no plans to implement ERM.

Though the methodology used by Beasley et al (2005) has some level of subjectivity in it, we will use it in this study to measure the level of ERM implementation because it is not industry specific, does not link ERM implementation to a single event and allows us to capture stages of implementation between the full state and non implementation. To mitigate the level of subjectivity in response, the study used Chief Internal Auditors as the respondents to the questionnaire. These targeted respondents provide some level of objectivity in the response given since they usually have a better understanding or ERM implementation in their companies.

Though previous research, (Beasley et al, 2005) used 5 levels of ERM implementation in the study, the levels are not clearly defined and cover a very wide scope of ERM implementation levels thus open to ambiguity and also lack the appreciation that at different levels of ERM implementation, the value derived differs. Therefore, in this research, I have selected our levels of ERM implementation of ERM from research done by the Economist Unit Intelligence Ltd, (2009) in which the levels have been broken down into distinct stages that would reduce any ambiguity in responses. I will also target the Chief Risk Officers and the Chief Internal Auditors of the companies in my population so as to increase the level of objectivity in the responses.

\subsection{Hypothesis}

Pagach and Warr (2007) investigate the characteristics of firms implementing ERM and find that firms that are more levered, have more volatile earnings and have exhibited poorer stock market performance are more likely to initiate an ERM program. The study also finds that when the value of the CEO's option and stock portfolio is increasing in stock volatility, the firm is also more likely to implement ERM. Several other studies have found that there are different firm characteristics that influence the level of ERM implementation in those companies. Some of these characteristics include;

Organization size: (Kleffner et al, 2003) suggests that larger firms would be more likely to adopt ERM because of the need for a more comprehensive risk management strategy. Hoyt et al (2008) also studies the value of Enterprise Risk Management in the US 
insurance industry and finds that ERM usage is positively related to firm size. The larger the organization, the more complex its operations will probably be and the more its exposure to threatening events. Besides that, the larger the organization, the more resources it will probably have to implement a more comprehensive ERM program. Consequently we investigate the following hypothesis.

Hypothesis 1 - Larger firms measured by asset base, are more likely to adopt ERM than smaller firms.

Industry of operations - The financial institutions globally seem to be at the forefront in implementing risk management due to the nature of business. Regulators in the financial services industry have come up with different regulations pushing companies in this industry to be at the forefront in implementing risk management. For example Basel II, Solvency II and Central Bank of Kenya risk management regulations among other financial institutions regulators others. The Economist Intelligence Unit (2001) examined six industries on ERM implementation and concluded that the financial services and utilities industries were more likely to be using ERM as their risk management strategy. Beasley et al (2005) also finds more extensive ERM implementation in the banking, education, and insurance industries. Therefore, we investigate the following hypothesis;

Hypothesis 2 - Companies in the financial services industry are more likely to implement ERM compared to other companies listed in the NSE.

Board independence - Kleffner et al (2003) studies the factors that affect the level of ERM implementation in companies in Canada. They investigated whether Corporate Governance has played any role in the decision for companies to adopt ERM. Their study concluded that support from the board of directors plays a key role in determining ERM adoption in the company. Beasley et al (2005) also studied the effect of board independence on the level of ERM implementation in companies and finds that more independent boards are positively associated with the company's level of ERM implementation. Board independence is usually associated with better corporate governance. Therefore, we investigate the following hypothesis;

Hypothesis 3 - The level of Board independence is positively associated with the Level of ERM implementation in companies.

Presence of a Chief Risk Officer (CRO)/Risk champion - Risk managers have an important role in the implementation of risk management in institutions. Liebenberg and Hoyt (2003) studied the determinants of ERM as evidenced by the appointment of a Chief Risk Officer and observed that though there was an absent explicit disclosure for ERM implementation, the appointment of a CRO can be taken as a strong signal of ERM implementation in the companies. Beasley et al (2005) also investigated whether the presence of a CRO is positively associated with the deployment of ERM. The study finds that the presence of a CRO/Risk champion in senior management significantly increases the entity's stage in ERM implementation. Therefore, we investigate the following hypothesis;

Hypothesis 4 - The presence of a CRO/Risk champion is positively associated with the company's stage of ERM implementation.

Growth - Beasley et al (2005) states that as companies growth rate increases, the scope of events threatening it are likely to differ in nature, timing, and extent. Therefore the faster a company is growing, the more likely it will embrace ERM. However, Hoyt et al (2008) finds no significant relationship between the rate of growth of a company and its level of ERM implementation. Allayannis and Weston (2001), control for the effect of growth opportunities on Tobin's Q using the ratio of R\&D expenditure to sales, or capital 
expenditure to assets. However, data related to R\&D expenditure was not available for this study thus consequently the study used historical (one-year) sales growth as a proxy for future growth opportunities. This method was also used in Feng-Li Lin (2010) and Hoyte et al (2008). We therefore investigate the following hypothesis;

Hypothesis 5 - The higher the rate of growth of a company, the higher the level of ERM implementation in the company

Table 1: Independent Variables

\begin{tabular}{|c|c|c|c|}
\hline & Initial & Description & Source \\
\hline Size & LNASST & $\begin{array}{l}\text { Represents organization size as a } \\
\text { measure of the natural log of the } \\
\text { organization's Asset base. }\end{array}$ & $\begin{array}{l}\text { Hoyt et al } \\
(2008)\end{array}$ \\
\hline $\begin{array}{ll}\text { Industry } & \text { of } \\
\text { Operation }\end{array}$ & INDU & $\begin{array}{l}\text { A variable representing the } \\
\text { industry as categorized in the NSE } \\
\text { market segmentation: 1- Finance } \\
\text { and investments, 2-Commercial } \\
\text { and Services, 3- Industrial and } \\
\text { allied, } 4 \text { - Agricultural }\end{array}$ & $\begin{array}{l}\text { Beasley et al } \\
(2005)\end{array}$ \\
\hline $\begin{array}{l}\text { Board } \\
\text { Independence }\end{array}$ & BODINDEP & $\begin{array}{l}\text { A variable for Board independence } \\
\text { and will be measured by the } \\
\text { percentage of independent board } \\
\text { directors. }\end{array}$ & $\begin{array}{l}\text { Kleffner et al } \\
(2003)\end{array}$ \\
\hline $\begin{array}{l}\text { Appointment of } \\
\text { a Chief Risk } \\
\text { Officer }\end{array}$ & CRO & $\begin{array}{l}\text { A dummy variable with } 1 \\
\text { representing the existence of a } \\
\text { CRO and } 0 \text { indicating non } \\
\text { existence of a CRO }\end{array}$ & $\begin{array}{l}\text { Liebenberg } \\
\text { and Hoyt } \\
(2003)\end{array}$ \\
\hline $\begin{array}{l}\text { Rate of } \\
\text { Company } \\
\text { Growth }\end{array}$ & GROWTH & $\begin{array}{l}\text { Measured as the percentage } \\
\text { increase in revenue of the } \\
\text { company. This variable is used to } \\
\text { measure whether the rate of growth } \\
\text { of a company has an effect on the } \\
\text { level of ERM implementation of } \\
\text { the company. }\end{array}$ & $\begin{array}{l}\text { Beasley et al } \\
(2005)\end{array}$ \\
\hline $\begin{array}{l}\text { ERM } \\
\text { regulatory } \\
\text { requirement }\end{array}$ & RGLT & $\begin{array}{l}\text { A dummy variable that indicates } \\
\text { whether implementation of ERM is } \\
\text { a regulatory requirement or not. }\end{array}$ & $\begin{array}{l}\text { Kleffner et al, } \\
2003\end{array}$ \\
\hline
\end{tabular}


Table 2: Dependent Variable

\begin{tabular}{|l|l|}
\hline ERM Level & Description \\
\hline ERM LEVEL $=6$ & $\begin{array}{l}\text { ERM framework is well formulated across the business and fully } \\
\text { implemented }\end{array}$ \\
\hline ERM LEVEL $=5$ & $\begin{array}{l}\text { ERM framework is well formulated across the business, with } \\
\text { implementation in progress and a clear timetable for completing } \\
\text { implementation. }\end{array}$ \\
\hline ERM LEVEL $=4$ & $\begin{array}{l}\text { ERM framework is well formulated across the business, with a } \\
\text { clear timetable for implementation but implementation has not } \\
\text { started. }\end{array}$ \\
\hline ERM LEVEL $=3$ & $\begin{array}{l}\text { ERM framework is a partially developed concept and there is no } \\
\text { clear timetable for implementation }\end{array}$ \\
\hline ERM LEVEL $=2$ & $\begin{array}{l}\text { No ERM framework is in place but there is a plan to introduce } \\
\text { one in the short-term }\end{array}$ \\
\hline ERM LEVEL $=1$ & No ERM framework and no plans to introduce one \\
\hline
\end{tabular}

Note: The Dependent Variable, ERM Level, reflects a value ranging from 1 to 6 (Beasley et al, 2005; Economist Intelligence Unit, 2009)

\subsection{ERM and Company Value}

For a long time it was believed that corporate risk management is irrelevant to the value of the firm and the arguments in favor of the irrelevance were based on the Capital Asset Pricing Model (Sharpe, 1964; Lintner, 1965; Mossin, 1966) and the Modigliani-Miller theorem (Modigliani and Miller, 1958). One of the most important implications of CAPM is that diversified shareholders should care only about the systematic component of total risk. On the surface it would appear that this implies that managers of firms who are acting in the best interests of shareholders should be indifferent about hedging of risks that are unsystematic. Miller and Modigliani's proposition supports CAPM findings.

It has been argued that, while traditional risk management is largely concerned with protecting the firm against adverse financial effects of risk, Enterprise Risk management makes risk management part of the company's overall strategy and enables companies to make better risk adjusted decisions that maximizes shareholder value (Lam and Kawamoto, 1997, Meulbroek, 2002). Hoyt et al, 2008, studies the value of ERM in the US insurance Industry by measuring the effect of ERM implementation on the value of the firm as measured by Tobin Q (ratio of company's market value to its replacement cost of assets).

Tobin suggested that the combined market value of all the companies on the stock market should be equal to their replacement costs, Tobin (1969) and Hayashi (1982). The Q ratio is theoretically defined as the market value of a company's assets divided by the replacement value of the company's assets. Then, when the assets are priced properly in the capital market, the $\mathrm{Q}$ ratio should be equal to one. In their survey of evidence of whether risk management adds value to companies, Smithson et al (2005) found that 9 studies on risk management and the value of the firm also used Tobin's $Q$ to proxy firm value.

This study uses the natural logarithm of Tobin's Q as a proxy for firm value because it dominates other performance measures. Unlike other measures, Tobin's Q does not 
require risk adjustment or normalization. Lindenberg and Ross (1981) also find Tobin's Q to reflect market expectations and as being relatively free from managerial manipulation. This study defines Tobin's Q as: - (market value of equity + book value of liabilities) / (book value of assets) (Cummins, Lewis \& Wei 2006; Chung and Pruitt, 1994).

Table 3: Variables being studied

\begin{tabular}{lll}
\hline Variable & Initial & Description \\
\hline ERM Level & ERM & The level of ERM implementation in the company \\
\hline & & \\
\hline Firm value & FIRM & The value of the firm measured by Tobin's Q \\
& VALUE & \\
\hline
\end{tabular}

\subsubsection{Control variables}

To distinctly isolate the relationship between ERM and value of the company, we need to control for other factors that could influence firm value (Liebenberg and Hoyt, 2003; Beasley et al, 2005; Hoyt et al, 2008). The controlling variables we will use are similar to those used by Hoyt et al (2008).Most literature on risk management assesses the value of risk management based on how institutions manage their financial risks using derivatives to hedge, and conclude for or against the value adding ability of risk management. However, there is very little research on how the integrated approach to risk management $(E R M)$, taking into account both financial and non-financial risk management activities, would have an effect on companies, in particular in emerging markets. Besides that, there seems to be limited research on factors associated with the implementation of ERM and how these factors affect the level of ERM implementation in companies in different markets. Therefore, this study seeks to find out the level of ERM implementation and significant factors influencing the ERM implementation by companies listed in the NSE, which is a developing market. The study also investigates whether, in a developing market like Kenya, ERM implementation has a significant positive effect on the value of the companies listed in the stock exchange.

Table 4: Control variables

\begin{tabular}{|c|c|c|}
\hline Variable & Initial & Rational \\
\hline Size & SIZE & $\begin{array}{l}\text { There is evidence that large firms are more likely to have } \\
\text { ERM programs in place (Colquitt et al, 1999, Liebenberg } \\
\text { and Hoyt, 2003, Beasley et al., 2005). Thus, it is necessary } \\
\text { to control for size in the model because the ERM indicator } \\
\text { may proxy for firm size. } \\
\text { This study uses the log of the book value of assets to control } \\
\text { for size related variations in Tobin's Q. }\end{array}$ \\
\hline Leverage & LVG & $\begin{array}{l}\text { To control for relationship between capital structure and the } \\
\text { company's value, this study includes a leverage variable that } \\
\text { is equal to the ratio of the book value of liabilities to the } \\
\text { market value of equity. }\end{array}$ \\
\hline Profitability & PROFIT & $\begin{array}{l}\text { Profitable firms are more likely to trade at a premium thus to } \\
\text { control for profitability this study includes return on assets } \\
\text { (ROA) in our regression model. }\end{array}$ \\
\hline
\end{tabular}




\begin{tabular}{|c|c|c|}
\hline Variable & Initial & Rational \\
\hline $\begin{array}{l}\text { Dividend } \\
\text { Policy }\end{array}$ & DIV & $\begin{array}{l}\text { This study will include in the model a dividend payment } \\
\text { indicator equal to } 1 \text { if the company paid dividend in the year } \\
2009 \text { and } 0 \text { if it did not }\end{array}$ \\
\hline $\begin{array}{l}\text { Growth } \\
\text { opportunities }\end{array}$ & GWTH & $\begin{array}{l}\text { Emulating Hoyte et al (2008), this research uses historical } \\
\text { (one-year) sales growth as a proxy for future growth } \\
\text { opportunities. }\end{array}$ \\
\hline
\end{tabular}

Drawing from contingency theory, the diagram below depicts the expected relationship between the factors that affect the level of ERM implementation in a company, the level of ERM implementation and the value of the company. The diagram shows how the level of ERM implementation in a company is contingent to several factors and in turn how the value of a company can be affected by the level of ERM implementation.

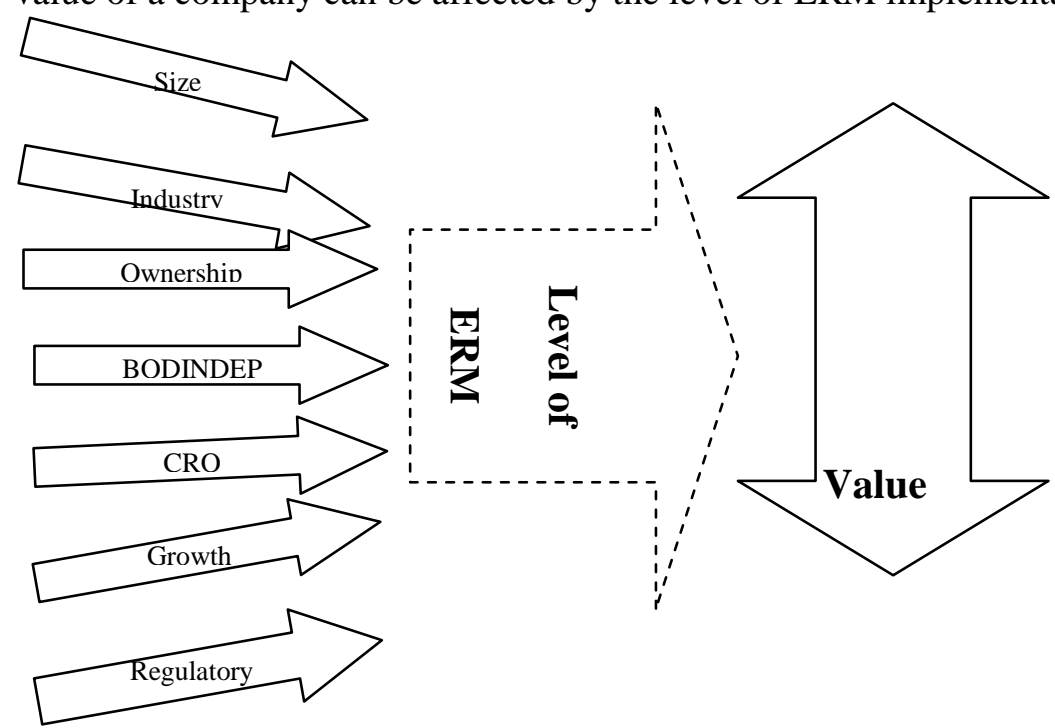

Figure 1: Contingency theory diagram

\section{Research Methodology}

This study only focused on companies listed in the Nairobi Stock Exchange because of the ease of availability of data on market value of companies listed in the stock exchange. There are 47 companies listed in the Nairobi stock exchange making it the biggest stock exchange in Eastern Africa with a market capitalization of over 1 trillion Kenyan shillings. The companies listed in the NSE are divided into four segments namely; Industrial and Allied, Agricultural, Commercial and Services and Finance and Investment. The market value data was used to compute the value of the companies measured using Tobin Q.

An email questionnaire was sent to the Chief Risk Officers (CRO) for all the 47 companies listed in the Nairobi stock. In the absence of a CRO, the questionnaires were emailed to the heads of internal audit or Chief Financial Officer. Two companies were however excluded from the study since they have been suspended from trading in the NSE. The questionnaires were used to gather information on the level of ERM implementation in the companies. The questionnaires were also used to collect the 
information on the perceived significance of factors affecting the level of ERM implementation in those companies. The questionnaire was designed from a collection of questions from similar research done on ERM (Hoyt et al, 2008; Beasley et al, 2005; Kleffner et al, 2003). Data related to the factors influencing the implementation of ERM was collected from the financial reports of the companies and the NSE website. ${ }^{5}$

Thereafter, the companies' financial statements were obtained from the company websites to collect information on the average size, growth, leverage and profit of the companies as at the last audited accounts. Information on the ownership and board's level of independence in the companies was also obtained from their financial statements. Data collected using the research questionnaire was analyzed using descriptive statistic to identify the mean and percentage of responses received. The data collected was presented in pie charts indicating the distribution of the different responses received.

A multivariate regression equation was used to analyze data on factors influencing ERM implementation and relationship between ERM and the value of the firm because it allows us to use several predictive variables simultaneously (Beasley et al, 2005). Information gathered for assessing the effect on ERM to the value of the firm was modeled into a multivariate regression;

FIRM VALUE = f [ERM LEVEL, SIZE, LVG, PROFIT, DIV, INSID, GWTH].

Table 5: Regression variables (Value of the Firm)

\begin{tabular}{|l|l|l|}
\hline Variable & Initial & Measured by; \\
\hline Size & SIZE & $\begin{array}{l}\text { We use the log of the book value of assets to control for size } \\
\text { related variations in Tobin's Q }\end{array}$ \\
\hline Leverage & LVG & $\begin{array}{l}\text { Equal to the ratio of the book value of liabilities to the market } \\
\text { value of equity. }\end{array}$ \\
\hline Profitability & PROFIT & Measured by return on assets (ROA). \\
\hline Dividend Policy & DIV & $\begin{array}{l}\text { Equal to 1 if the company paid dividend in the year 2009 and 0 if } \\
\text { it did not }\end{array}$ \\
\hline $\begin{array}{l}\text { Growth } \\
\text { opportunities }\end{array}$ & GWTH & $\begin{array}{l}\text { Historical (one-year) sales growth as a proxy for future growth } \\
\text { opportunities. }\end{array}$ \\
\hline
\end{tabular}

Table 6: Factors influencing ERM implementation

\begin{tabular}{|l|l|l|}
\hline & Initial & Description \\
\hline Size & LNAST & $\begin{array}{l}\text { Represents organization size as a measure of the } \\
\text { natural log of the organization's Asset base. }\end{array}$ \\
\hline Industry of Operation & INDU & $\begin{array}{l}\text { A variable representing the industry as categorized } \\
\text { in the NSE market segmentation: 1- Finance and } \\
\text { investments, 2-Commercial and Services, 3 - } \\
\text { Industrial and allied, 4 - Agricultural }\end{array}$ \\
\hline Board Independence & BODINDEP & $\begin{array}{l}\text { A variable for Board independence and will be } \\
\text { measured by the percentage of independent board } \\
\text { directors. }\end{array}$ \\
\hline Appointment of a Chief Risk & CRO & A dummy variable with 1 representing the \\
\hline
\end{tabular}

5 The study used December 2009 financial statements for companies whose year end is in December and used year 2010 financial statements for companies whose year ends fall between January and June. 


\begin{tabular}{|l|l|l|}
\hline Officer & & $\begin{array}{l}\text { existence of a CRO and 0 indicating non existence } \\
\text { of a CRO }\end{array}$ \\
\hline Rate of Company Growth & GROWTH & $\begin{array}{l}\text { Measured as the percentage increase in revenue of } \\
\text { the company. This variable is used to measure } \\
\text { whether the rate of growth of a company has an } \\
\text { effect on the level of ERM implementation of the } \\
\text { company. }\end{array}$ \\
\hline $\begin{array}{l}\text { ERM a regulatory } \\
\text { requirement }\end{array}$ & RGLT & $\begin{array}{l}\text { A dummy variable that indicates whether } \\
\text { implementation of ERM is a regulatory } \\
\text { requirement or not. }\end{array}$ \\
\hline
\end{tabular}

Following our hypotheses development in Section 2.3, we specify another ordinary least squares OLS) regression model to test for the significant factors influencing the adoption of ERM (see table 3.2 above):

ERM LEVEL = f [LNAST, INDU, BODINDEP, CRO, GROWTH, RGLT].

\section{Findings}

\subsection{Level of ERM implementation in listed companies}

Thirty Six percent of the respondents indicated that their companies that they don't have an ERM framework in place but had plans to introduce one in the short run. Twenty Seven percent of the respondents on the other hand indicated that their companies have fully implemented an ERM framework across the company.

Table 7: State of ERM implementation

\begin{tabular}{|l|l|l|}
\hline ERM State & Response & \%age response \\
\hline $\begin{array}{l}\text { ERM framework is well formulated across the business } \\
\text { and fully implemented }\end{array}$ & 6 & $27 \%$ \\
\hline $\begin{array}{l}\text { ERM framework is well formulated across the business, } \\
\text { with implementation in progress and a clear timetable for } \\
\text { completing implementation. }\end{array}$ & 3 & $14 \%$ \\
\hline $\begin{array}{l}\text { ERM framework is well formulated across the business, } \\
\text { with a clear timetable for implementation but } \\
\text { implementation has not started. }\end{array}$ & 1 & $5 \%$ \\
\hline $\begin{array}{l}\text { ERM framework is a partially developed concept and } \\
\text { there is no clear timetable for implementation }\end{array}$ & 4 & $18 \%$ \\
\hline $\begin{array}{l}\text { No ERM framework is in place but there is a plan to } \\
\text { introduce one in the short-term }\end{array}$ & 8 & $36 \%$ \\
\hline No ERM framework and no plans to introduce one & 0 & $0 \%$ \\
\hline
\end{tabular}

No respondent indicated that they had no plans of introducing an ERM framework. These results indicate that all the companies listed in the NSE recognize some benefit of implementing ERM whether from an anticipated regulatory compliance perspective or from a business value addition perspective. However, most companies are still at the planning stage especially industries where ERM is not a regulatory requirement. With and 
exception of two companies, all the other companies that indicated that they have fully implemented an ERM framework were in the financial services industry where ERM implementation is a regulatory requirement.

Based on the study findings, only $18 \%$ of the respondents viewed ERM as a compliance function with a key focus to satisfying regulatory requirements. The other $82 \%$ of the respondents viewed ERM as a value adding business partner with a key role to value addition to the business. This could be an indication that the respondents expect that the implementation of ERM will have a positive effect on the value of the companies.

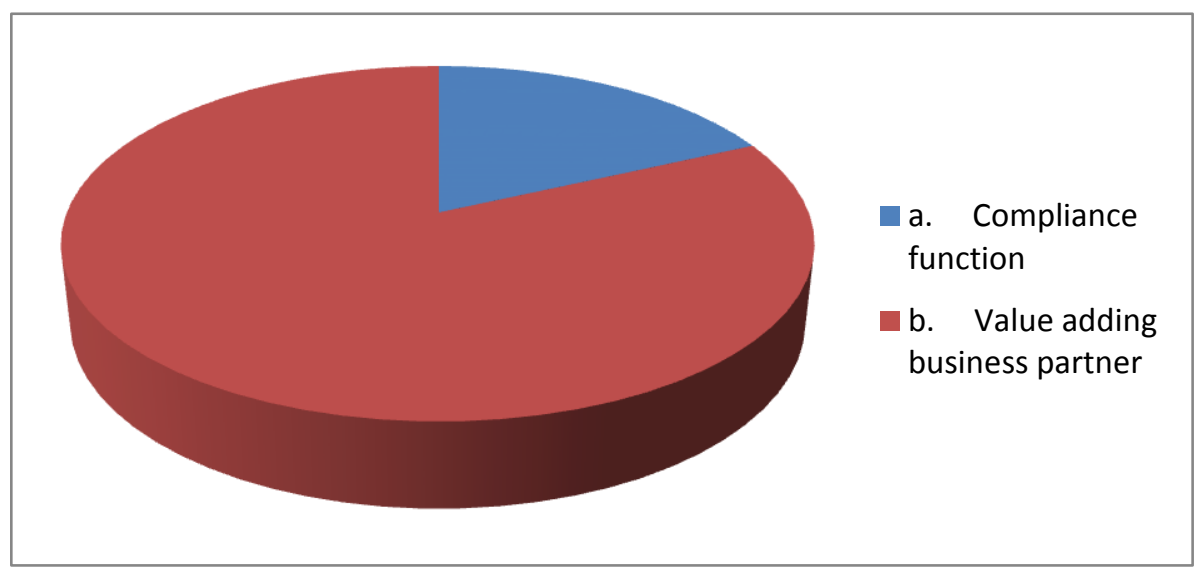

Figure 2: Respondents view of Enterprise Risk Management Implementation

Although Mazier (2001) concluded that the Enterprise Risk Management function varies from company to company, the study did not identify what company characteristics engineer this variation. However, in a survey done by PWC (2007) where 400 senior executives in financial services, the authors found out that some executives think their organizations' risk management function is most effective at ensuring regulatory compliance; and they identify better relationships with regulators as the most common source of competitive advantage from successful risk management. In other words, there appears to be a tendency among respondents for successful risk management to be defined in regulatory terms. This study arrives at a different conclusion from that of PWC (2007) because $82 \%$ of the respondents view ERM implementation as a value adding business initiative rather than a regulatory compliance initiative.

The findings are consistent with those of Tillinghats-towers Perrin survey (2002) that found that less than half of companies surveyed in the US cited regulatory requirement as motivator for ERM implementation. However, the study also found that more that $70 \%$ of respondents from Canadian firms cited regulatory pressure as a key motivator for ERM implementation. Tom Aabo (2004) relates a company views its ERM activities as compliance activities or value adding business activities to shareholder theory. The study concluded that companies that focus more on stakeholders view ERM as a compliance activity while those that have a primary focus on Shareholders view ERM implementation as a value adding business activity. From the study findings (Aabo, 2004), and the results from this study, we therefore can infer that most of the companies listed in the NSE have a primary orientation towards shareholder value addition as compared to stakeholders value addition.

Although different companies have different measures for the value of implementing risk 
management, $50 \%$ of the respondents measure the value of their risk management activities through a reduction in earnings volatility.

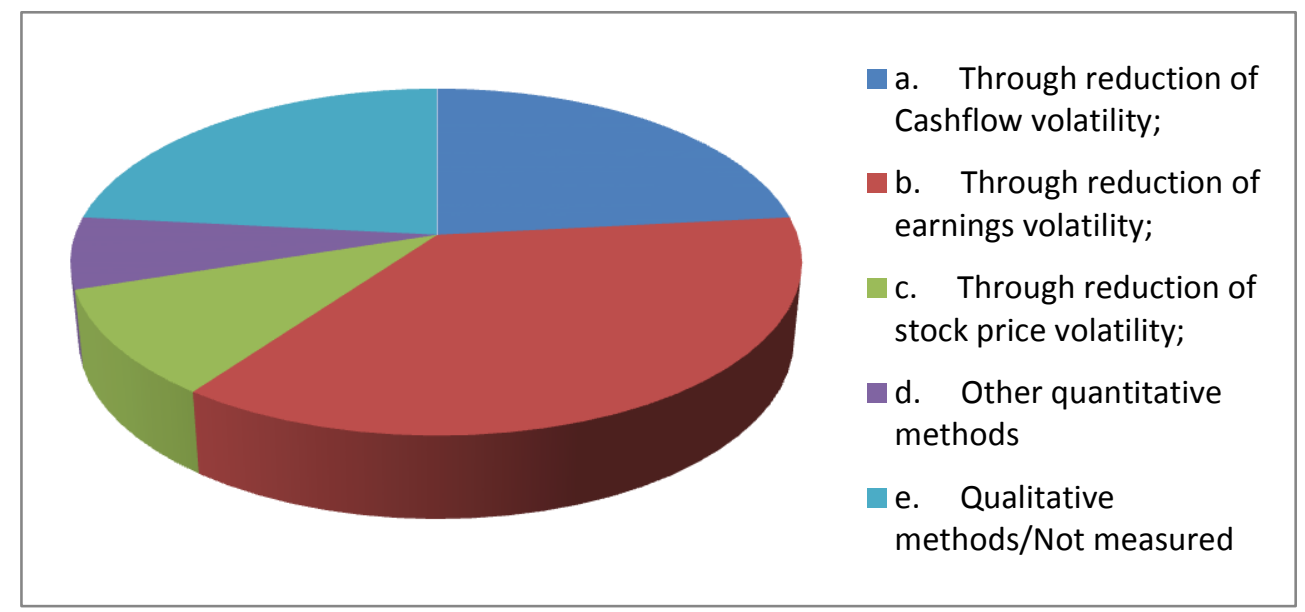

Figure 3: How ERM value is measured

There is no agreement on which is the most common measure for the value of ERM, different studies have used different measures. For example, Panning (2006) uses discounted future earnings thus earnings volatility was a key measure in the study. The study notes that the volatility of profit leads to a lower value to at least some of the company's stakeholders thus a good measure for firm value. Liebenberg (2003) also points out that implementation of ERM reduces a companies' earnings volatility by preventing the aggregation of risk across different sources thus increasing the companies' value. Klimczak (2007) on the other hand measures the value through reduction of Cashflow volatility. Though this study finds that $50 \%$ of the companies in the NSE measure the value of their ERM programs through its reduction of earnings volatility, this method has some inherent weaknesses including; identifying what portion of the earning volatility can be directly attributed to the ERM initiatives as compared to other variables that also affect earnings, volatility and also translating the reduction in earnings volatility to actual company valuation.

Forty Five percent of the respondents indicated that ERM implementation in their companies are championed by a Chief risk officer/risk champion while $36 \%$ indicated that this implementation is championed by the head of internal Audit. The high percentage of respondents indicating that ERM implementation is championed by a Chief Risk Officer is attributed to the fact that most of the sampled respondents who responded to the questionnaire were from banks and the Central Bank of Kenya has a requirement that all banks should appoint a Chief Risk Officer to champion their risk management initiatives. The high percentage of respondents who indicated that their risk management activities are championed by a CRO or internal audit is consistent with the findings of Haubenstock (1999) that it's better for risks to be managed via a single organizational unit that bears direct responsibility for supervising the entire process rather than via a committee or group. 


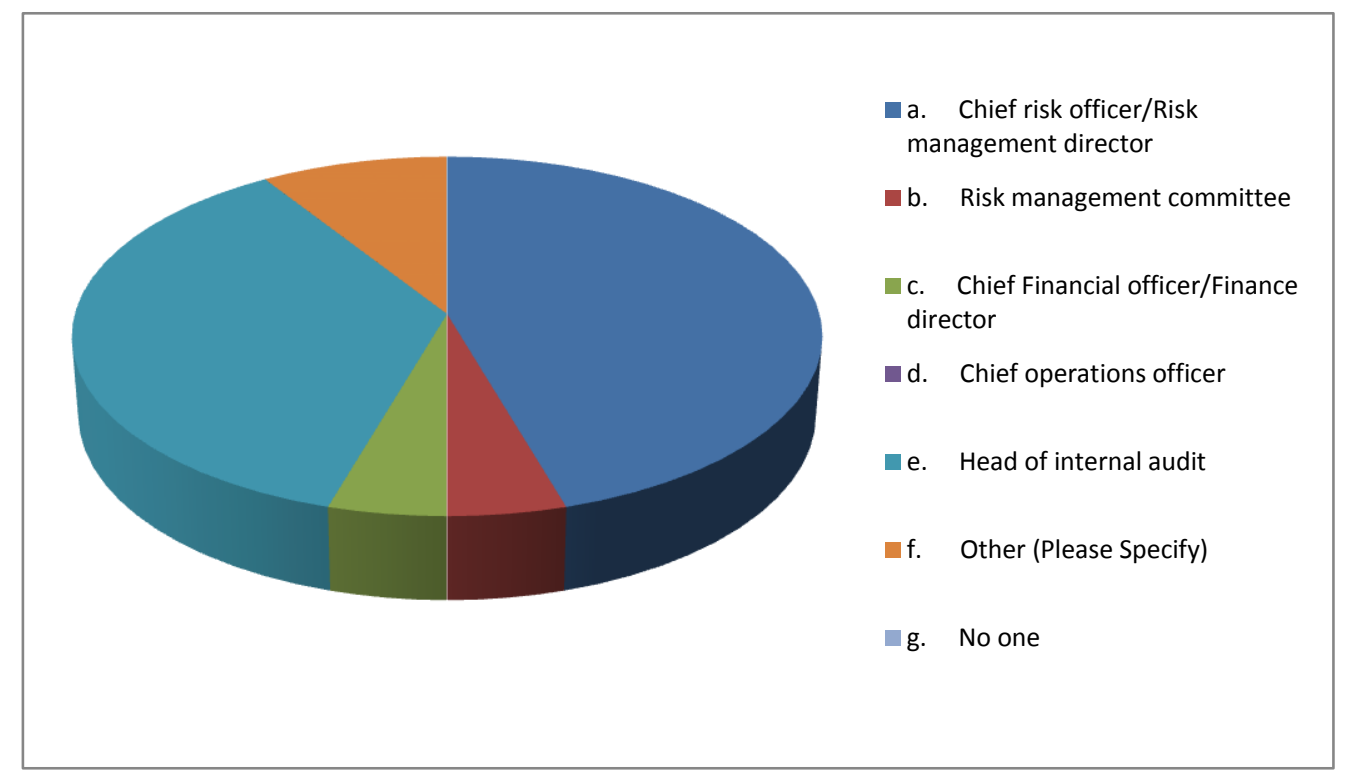

Figure 4: Responsibility for ERM

\subsection{Regression Analysis (Firm value and ERM)}

The results of the regression analysis are shown in Tables 4.3, 4.4 and 4.5.

Table 8: Descriptive Statistics

\begin{tabular}{|l|l|l|l|l|l|l|}
\hline Variable & $\begin{array}{l}\text { Observ } \\
\text { ations }\end{array}$ & Mean & Min & Median & Max & StDev \\
\hline ERM Level & 22 & 3.55 & 2.00 & 3.00 & 6.00 & 1.68 \\
\hline Tobin Q & 22 & 0.88 & 0.13 & 0.44 & 2.98 & 0.89 \\
\hline Size & 22 & 24.11 & 21.56 & 24.28 & 26.00 & 1.33 \\
\hline Leverage & 22 & 2.15 & 0.04 & 1.89 & 7.30 & 2.00 \\
\hline Profitability & 22 & 0.07 & 0.01 & 0.04 & 0.23 & 0.07 \\
\hline Div paid & 22 & 0.86 & - & 1.00 & 1.00 & 0.35 \\
\hline Growth & 22 & 0.25 & $(0.02)$ & 0.20 & 1.65 & 0.35 \\
\hline
\end{tabular}

The above table represents the descriptive statistics of the variables used in the regression model. From the descriptive statistics, the study finds that the highest level of ERM implementation in the NSE is in companies that have managed to fully implement their ERM framework with the lowest being companies that still plan to implement ERM in the 
short run but are yet to develop the ERM framework. The average value of listed companies as measured by Tobin's Q is 0.88 . This value is higher than the $\mathrm{Q}$ value of most of the sampled companies because of a few respondent companies that had relatively high Q ratios. Mean ERM level of 3.55 indicates that on the average, companies listed in the NSE either have an ERM framework that is a partially developed concept and there is no clear timetable for implementation or have an ERM framework with an implementation timetable but implementation hasn't begun. This finding is consistent with the findings of The Economist Intelligence Unit (2009) which found that on the average, respondents had implemented an ERM strategy but had not communicated the strategy well across departments. This was also the case in Beasley (2005).

Table 9: Pearson correlations

\begin{tabular}{lllllll}
\hline & $\begin{array}{l}\text { ERM } \\
\text { Level }\end{array}$ & Tobin Q & Size & Leverage & Profitability & $\begin{array}{c}\text { Div } \\
\text { Paid }\end{array}$ \\
\hline Tobin Q & -0.074 & & & & \\
Size & $0.503 * *$ & $-0.459^{* *}$ & & & \\
Leverage & 0.219 & $-0.726 * * *$ & $0.487 * *$ & & \\
Profitability & -0.159 & $0.880^{* * *}$ & -0.181 & $-0.659 * * *$ & & \\
Div Paid & -0.271 & 0.005 & 0.078 & $-0.457 * *$ & 0.109 & \\
Growth & -0.159 & -0.146 & -0.186 & 0.001 & -0.214 & -0.002
\end{tabular}

The significance of the coefficients is obtained using the p-values with $*$, ** and $* * *$ denoting significance at the $10 \%, 5 \%$ and $1 \%$ levels respectively.

The independent variables are not highly correlated against each other (most have a correlation of less than 0.7), suggesting that multi-collinearity is not a significant factor ((Tibachnick and Fidel, 1996).

Table 10: Regression results (ERM Level vs. Firm value)

\begin{tabular}{|l|l|l|l|l|}
\hline Variable & Coefficient & T-Value & P-Value & VIF \\
\hline ERM Level & 0.15766 & 3.02 & 0.009 & 2.1 \\
\hline Size & -0.30711 & -3.70 & 0.002 & 3.3 \\
\hline Leverage & 0.00045 & 0.01 & 0.995 & 5.5 \\
\hline Profitability & 11.260 & 7.20 & 0.000 & 2.9 \\
\hline Div Paid & 0.0772 & 0.27 & 0.790 & 2.7 \\
\hline Growth & -0.0113 & -0.06 & 0.952 & 1.1 \\
\hline
\end{tabular}

The coefficient of determination for the regression model ( $\mathrm{R}-\mathrm{Sq}$ ) is $\mathbf{9 2 . 9 \%}$. This is an indication that the model has a strong explanatory power. The $\mathbf{F}$ ratio is used to test whether the model as a whole has statistically significant predictive capability. This model has an $\mathrm{F}$ ratio of 32.83 with a p-value of 0.000 thus the model has a statistically significant explanatory power. 
This study also uses the Variance Inflation Factors (VIF) to test for multi-collinearity in the linear equation. The results show that all the VIF values are less than the rule of the thumb of 10, (Kutner, Nachtsheim, Neter, 2004) hence multi-collinearity is not considered a serious problem.

According to the regression analysis results, the study finds that there is a significant relationship between the value of the firm and the Level of ERM implementation, the company's size and the profitability of the firm. Consistent with Hoyt et al (2008) and Beasley et al (2005) this study finds that the implementation of ERM has a strong positive linear effect on the value of the company. The coefficient on ERM level is positive and significant. The coefficient estimate of 0.157 indicates that companies engaged in ERM are valued at $15.7 \%$ higher than other companies. This finding s similar to that of Hoyte et al (2008) that found that insurance companies engaging in ERM are valued at $16.7 \%$ higher than other insurance companies.

In line with evidence that large firms are more likely to have ERM programs in place (Colquitt et al, 1999, Liebenberg and Hoyt, 2003, Beasley et al., 2005), this study also finds that the size of the organization has a significant influence of the value of the firm. Allayannis and Weston (2001) also found that profitable firms are more likely to trade at a premium thus a positive relationship between a company's profitability and its value as measured by Tobin's Q.

Leverage, dividend paid and growth were found not to have a significant influence on the value of companies as measured by Tobin's Q. This is partially consistent with Hoyte et al (2008) who did not find a significant relationship between the value of the firm and the growth and leverage variables of the firm. However they found a positive relationship between dividend paid and value of the firm with the notion that dividend payments are a valuable method of reducing agency costs associated with free cash flow. This notion doesn't seem to hold in companies listed in the NSE.

\subsection{Significance of Factors Affecting Level of ERM Implementation}

From the descriptive statistics this study finds that $45 \%$ of the entities have appointed a Chief Risk Officer and Boards of directors, on average, have $50 \%$ of their members representing independent directors. On the average, $41 \%$ of the respondents were required to implement ERM by the industry regulators in the industry they operate in.

In the second equation, we model the level of ERM implementation as a function of factors expected to affect the level of the ERM implementation. Our ERM implementation model sheds light on the significance of some of the determinants of ERM activity among listed companies. The model has an explanatory power (R-Sq) of $59.8 \%$ with an F-ratio of 4.77 and p-value of 0.007 thus the model has a statistically significant explanatory power. The multivariate regression results are presented in the Table 13. 
Table 11: Descriptive Statistics Results

\begin{tabular}{|l|l|l|l|l|l|l|}
\hline Variable & Observations & Mean & Min & Median & Max & StDev \\
\hline INDU & 22 & 1.64 & 1.00 & 1.00 & 3.00 & 0.79 \\
\hline LNAST & 22 & 24.11 & 21.56 & 24.28 & 26.00 & 1.33 \\
\hline BODIND & 22 & 0.50 & 0.10 & 0.50 & 0.78 & 0.15 \\
\hline CRO & 22 & 0.45 & 0 & 0 & 1.00 & 0.51 \\
\hline GROWTH & 22 & 0.25 & $(0.02)$ & 0.20 & 1.65 & 0.35 \\
\hline
\end{tabular}

Table 12: Pearson Correlation Matrix

\begin{tabular}{llllll}
\hline & ERM & INDU & LNAST & BODINDEP & CRO \\
& LEVEL & & & & \\
\hline INDU & 0.034 & & & & \\
LNAST & 0.017 & 0.135 & & & \\
BODINDEP & $0.418^{* *}$ & $0.403^{* *}$ & $0.723^{* * *}$ & & \\
CRO & 0.000 & 0.002 & 0.000 & 0.187 & \\
GROWTH & $0.479^{* *}$ & 0.181 & $0.407^{* *}$ & $0.908^{* * *}$ & $0.850^{* * *}$ \\
\hline
\end{tabular}

The significance of the coefficients is obtained using the p-values with $*, * *$ and $* * *$ denoting significance at the $10 \%, 5 \%$ and $1 \%$ levels respectively

Table 13: Regression analysis

\begin{tabular}{|l|l|l|l|l|}
\hline Variable & Coefficient & T stat & p-value & VIF \\
\hline INDU & 0.0084 & 0.02 & 0.987 & 2.1 \\
\hline LNAST & -0.2452 & -0.77 & 0.455 & 2.6 \\
\hline BODINDEP & -0.766 & -0.39 & 0.703 & 1.2 \\
\hline CRO & 3.009 & 2.86 & 0.011 & 4.0 \\
\hline GROWTH & -0.7410 & -0.87 & 0.397 & 1.2 \\
\hline
\end{tabular}

This study also uses the Variance Inflation Factors (VIF) to test for multi-collinearity in the linear equation. The results show that all the VIF values are less than the rule of the thumb of 10, (Kutner, Nachtsheim, Neter, 2004) hence multi-collinearity is not considered serious.

\subsection{Hypothesis analysis}

This study finds a positive relationship between the level of ERM implementation and the appointment of a Chief Risk Officer in the company. This relationship is found to be statistically significant $(\mathrm{p}=0.011)$. This findings are consistent with those of Beasley et al (2005) and Liebenberg and Hoyt (2003) who also found a positive and significant relationship between the appointment of a CRO and the level of ERM implementation in companies.

From the regression results, industry of operation has a positive coefficient with a p-value of 0.987 . This indicates that though there is a positive relationship between industry of operation and the level of ERM implementation, the relationship is not significant. This is 
inconsistent with prior research, The Economist Intelligence Unit (2001) and Beasley et al (2005) that found that the financial services and utilities industries were more likely to be using ERM as their risk management strategy as compared to other industries.

The regression results indicate that there is a negative relationship between the size of the firm and the level of ERM implementation at the firm. This is inconsistent with Kleffner et al, (2003) and Hoyt et al (2008) who suggested that larger firms are more likely to adopt ERM because the larger the organization, the more complex its operations will probably be and the more its exposure to threatening events. However, the p-value of 0.546 indicates that this relationship is not statistically significant and this finding is consistent with the findings of Beasley (2005) where the relationship between the level of ERM implementation and the size of the company were found not to be statistically significant.

The regression results indicate that there is a negative relationship between the level of board independence and the level of ERM implementation of companies. However this relationship is considered not statistically significant $(\mathrm{p}=0.918)$. This finding differs from that of Beasley et al (2005) who found that a more independent board has a significant positive influence on the level of ERM implementation in a company.

Finally, this study sought to investigate if there is a relationship between the rate of growth of companies and their level of ERM implementation. From the regression results, the study finds a negative but insignificant relationship between the rate of growth in companies and the level of ERM implementation. This finding is consistent with Hoyt et al (2008) that found no significant relationship between the rate of growth of a company and its level of ERM implementation.

\section{Discussions}

The research findings show that most of the companies listed in the NSE have not implemented an ERM framework but have plans to implement one in the short run. This finding differs from that of The Economist Intelligence Unit (2009) which found a bigger percentage of its respondents $(26 \%)$ had implemented an ERM strategy but had not communicated the strategy well across departments. The biggest percentage of respondents (41\%) in Beasley (2005) also indicated that they had partially implemented ERM. The findings of this study could have been influenced by the fact that ERM is still a new phenomenon in Kenya having gained momentum in 2005 with the introduction of a regulatory requirement by the central bank of Kenya requiring that all banks implement and enterprise Risk management Framework.

Eighty Two percent of the respondents indicated that their companies view ERM as a strategic business partner as compared to $18 \%$ who indicated ERM as a compliance initiative. This is inconsistent with the PWC (2007) survey that concluded that most companies implement ERM as a result of regulatory pressure. However, the findings are consistent with Tillinghats-towers Perrin survey (2002) that found that less than half of companies surveyed in the US cited regulatory requirement as motivator for ERM implementation. With reference to Aabo (2004) which related companies' view of ERM to shareholder theory, we can conclude that since most companies surveyed viewed ERM as a business partner, it therefore follows that this companies have a primary focus on growing shareholder value as compared to stakeholder value.

The findings also show that $45 \%$ of the respondent's companies have a Chief risk officer 
who champions the implementation of ERM while in $36 \%$ of the companies; ERM is championed by the head of internal audit. Consistent with contingency theory, this study found that the appointment of a Chief Risk Officer had a significant influence on the level of ERM implementation. This finding is consistent with Liebengerg (2003) that found that firms appoint CRO's to reduce information asymmetry regarding the company's current and expecte $3 \mathrm{~d}$ risk profiles thus better implementation of risk management.

The significant and positive coefficient for existence of a CRO/Risk champion suggests that the presence of this position is positively associated with the extent of ERM deployment. This finding suggests that the presence of a "risk champion" among the senior management team significantly increases the entity's stage of ERM deployment. The findings of the study are consistent with those of Beasley et al (2005) and Liebenberg and Hoyt (2003) that concluded that this finding suggests that the presence of a "risk champion' among the senior management team significantly increases the entity's stage of ERM implementation. However, whereas those studies also found that board independence and industry of operation had a significant influence on the level of ERM implementation of companies, these papers did not find any significant relationship between this variables and the level of ERM implementation in companies.

Therefore, though contingency theory contends that there is no one best way of organizing and that an organizational style that is effective in some situations may not be successful in others (Fiedler, 1964), this study finds that the level of implementation of ERM in companies listed in the NSE is significantly related to the appointment of a $\mathrm{CRO} /$ Risk champion but not significantly related to the other variables of study. This finding seems to suggest that there is one "best way" of getting a company to increase its level of ERM implementation and this is by appointing a Chief Risk Officer or Risk Champion. The findings of this study might be inconsistent with contingency theory because ERM implementation is still at its infancy stage in Kenya having picked up in the year 2005 thus the reason it's only significantly influenced by one variable that is related with its initiation in an organization. Therefore, for corporate executives of companies in Kenya to advance in their levels of ERM implementation so as to reap the benefits of its value addition to companies, they should ensure that their organizations appoint a risk champion at senior management level to lead their risk management initiatives.

In investigating whether the level of ERM implementation has a significant positive effect on the value of companies, this study found that the level of ERM had a significant positive contribution to the value of the firm as measured by Tobin's Q. This finding contradicts studies undertaken by Modigliani and Miller (1958), Sharpe (1964), Lintner (1965), Nain (2004), Lookman (2004) and Jin and Jorion (2005). This studies concluded that implementation of risk management strategies is irrelevant to the firms value.

However, the research findings in this study are consistent with literature reviewed, that indicates that there is a significant relationship between the level of ERM implementation and value of the company (Hoyt et al 2008; Beasley et al, 2005; Kleffner et al, 2003). This is evidenced by the results from the regression model with a positive and statistically significant coefficient for the level of ERM implementation. Lam and Kawamoto (1997) and Meulbroek (2002) also found that Enterprise Risk management makes risk management part of the company's overall strategy and enables companies to make better risk adjusted decisions that maximizes shareholder value. As discussed by Hoyte et al (2008), firms that engage in ERM are able to better understand the aggregate risk inherent in different business activities.

The findings of this study suggest that companies that have their primary focus on adding 
shareholder wealth should implement ERM as it does contribute to the company's market value. Therefore, an ERM level positive coefficient of 0.157 indicates that companies that implement ERM in the NSE are valued at $15.7 \%$ higher than those that have not implemented ERM.

\section{Conclusions and Implications}

The first objective of this study was to identify the general state of ERM implementation in companies listed in the Nairobi Stock Exchange. The second objective was to investigate whether the implementation of ERM has a positive effect on the value of the companies that implement it. The third objective of the study sought to assess the significant factors affecting the level of implementation of ERM in those companies. A qualitative research was undertaken with two regression models being formulated to test whether the implementation of ERM has a significant effect on the value of the company implementing it and to test for significance of factors that have an effect on the implementation of ERM in companies. The key findings of this study indicate that the level of ERM implementation has a significant effect on the value of the companies that implement it. These findings provide an indication that regardless of the differences between developed and emerging markets, the implementation of ERM has a positive effect on the value of companies. This finding is important in motivating corporate executives to make a deeper commitment to implementation of ERM so as to return more value to their shareholders. Furthermore this study provides some initial exploratory empirical evidence that highlights whether the implementation of ERM has a value addition effect on companies or not and assesses several factors associated with the organization's extent of ERM implementation and their significance to that implementation. The findings of the study show that companies can add to their shareholders value by implementing ERM thus have a competitive advantage over companies that have not implemented ERM or are at earlier stages of implementation.

The results suggest that though other organization characteristics like board independence, industry of operation, regulatory requirements and rate of growth of the company do not have a significant effect on the level of ERM implementation in companies, the appointment of a Chief Risk officer is critical to the level of implementation of ERM in companies. This finding is important for organizations to in implementing policies for risk management since it indicates that for the policies to be effective, the organization needs to appoint a risk management champion/chief risk officer at a senior management level.

This study provides an initial base that can trigger additional research on ERM. The academic community is positioned to greatly contribute to this growing public policy need for more effective enterprise risk management and corporate governance in both the private and public sector organizations.

This study was not without limitations. First, it was difficult to measure the level of ERM implementation with limited subjectivity since we relied on questionnaire responses to identify the level of ERM implementation in the respondents companies. Secondly, only $22(49 \%)$ of the targeted population responded to the questionnaire and most of the respondents were from the financial services segment thus there is a probability of industry bias in the research findings. Using email questionnaires in this study had a limitation in terms of response rate from the targeted respondents thus a contribution to 
the low response rate. The small sample size of only 22 respondents also limited the extent of our statistical analysis.

\section{References}

[1] Allayannis, G and Weston, J. (2001). The Use of Foreign Currency Derivatives and Firm Market Value, Review of Financial Studies, 14, (2001), 243-276.

[2] Appiah-Kusi, J and Menyah, K., Return predictability in African stock markets. Review of Financial Economics, 12, (2003), 247-270.

[3] Barton, T.L., Shenkir, W.G., and Walker, P.L., "Making enterprise risk management pay off: How leading companies implement risk management", Financial Times Prentice Hall, Pearson Education, Inc (2002).

[4] Beasley, M.S., Clune, R and Hermanson, D.R., Enterprise risk management: An empirical analysis of factors associated with the extent of implementation, Journal of Accounting and Public Policy, Vol.24, (2005), 521-531.

[5] Casualty Actuarial Society Advisory Committee on Enterprise Risk Management, Report of the Advisory Committee on Enterprise Risk Management, (2001) [Online] Available: http://www.casact.org/research/erm/report.pdf; retrieved January 20th 2011

[6] Chung, K.H. and Pruitt, S.W., A simple approximation of Tobin's q, Financial Management 23, (1994), 70-74.

[7] Collins, J.M. and Ruefli, T.W. (1992), "Strategic risk: an ordinal approach", Management Science, Vol. 38, (1992),1707-31.

[8] Committee of Sponsoring Organizations of the Treadway Commission (COSO), Enterprise Risk Management-Integrated Framework, (2004), [Online] Available: http://www.coso.org; retrieved Nov 18th 2009,.

[9] Cumming, C.M and Hirtle, B.J, The Challenges of Risk Management in Diversified Financial Companies, Economic Policy Review, Federal Reserve Bank of New York (2001).

[10] Cummins, J. D, Lewis, C M. and Wei, R, The Market Value Impact of Operational Risk Events for U.S. Banks and Insurers, (2004) [Online] Available; http://ssrn.com/; Retrieved on 15th August 2010

[11] Cyree, K. \& Huang, P. ( 2004), "Bank Hedging and Derivatives Use: The Impact on and Sources of Shareholder Value and Risk," Working paper, University of Mississippi and Massey University

[12] Davenport, E.W., and Bradley, L.M, Enterprise risk management: A consultative perspective, (2001), [Online] Available: http://www.casact.com; retrieved January 28, 2009

[13] Davies, D., Eckberg, C., and Marshall, A., "The Determinants of Norwegian Exporters' Foreign Exchange Risk Management", The European Journal of Finance, Vol. 12, No. 3, (2006), 217-240

[14] Deloitte, Assessing the Value of Enterprise Risk Management, (2004), [Online] Available: http://www.deloitte.com/; retrieved on 19th January 2009,

[15] Deloitte, Enterprise Risk Management (ERM) Success through intelligent risk taking, (2007), [Online] Available: http://www.deloitte.com/ ; retrieved on 19th January 2009,

[16] Dickinson, J.P \& Muragu K., Market efficiency in developing countries: A case 
study of the Nairobi Stock Exchange. Journal of Business and Accounting, 21 (1994): 133-150.

[17] Economist Intelligence Unit Limited and MMC Enterprise Risk.Inc, Enterprise Risk Management: Implementing new solutions, New York (2001).

[18] Economist Intelligence Unit Limited and MMC Enterprise Risk.Inc, After the Storm: A new era for risk management in financial services, New York (2009).

[19] E.E Mazier, CRO's Must Go Beyond Numbers, Property and Risk Causality/Risk and Benefits management, (2001), 20

[20] Faulkender, M., "Hedging or Market Timing? Selecting the Interest Rate Exposure of Corporate Debt", The Journal of Finance, Vol. 60, No. 2, (2005), 931-963.

[21] Füss, R., "The Financial Characteristics Between Emerging and Developed Equity Markets." Paper presented at the Policy Modeling International Conference, EcoMod Network, Brussels, (2002), July, 4-6.

[22] Haubenstock, M, Organizing a Financial Institution to Deliver Enterprise-Wide Risk Management, Journal of lending and Credit Management, February 1, (1999), 46-52

[23] Hayashi, F., Tobin's marginal q and average q: A neoclassical interpretation." 50, (1982) 213-224.

[24] Hoyt, R.E., Moore, D. and Liebenberg, A.P, The Value of Enterprise Risk Management: Evidence from the U.S Insurance Industry, (2008), [Online] Available: http://www.soa.org/library/monographs/other-monographs/2008/april/mono-2008-m -as08-1-hoyt.pdf; Accessed on $13^{\text {th }}$ June 2010

[25] Innes, J., and Mitchell, F., "The process of change in management accounting: some field study evidence", Management Accounting Research, Vol. 1 No.1, (1990), 3-19

[26] Ivancevich, D.M., Hermanson, D.R and Smith, L.M., The association of perceived disaster recovery plan strength with organizational characteristics, Journal of Information Systems, Spring, (1998), 31-40.

[27] Jin, Y. and Jorion, P., "Firm Value and Hedging: Evidence from U.S. Oil and Gas Producers", Working paper, California State University at Northridge and University of California at Irvine (2004).

[28] Kleffner, A.E., Ryan, B.L and McGannon B., The effect of corporate governance of the use of enterprise risk management, Risk Management and Insurance Review, Vol.6, No.1, (2003), 53-73.

[29] Klimczak, K.M., Risk Management Theory: A comprehensive empirical assessment, (2007) [Online]Available; http://mpra.ub.uni-muenchen.de/4241/; Accessed on 07. November 2010

[30] Kutner, M Nachtsheim, C and Neter, J, Applied Linear Regression Models, 4th edition, McGraw- Hill Irwin, Boston (2004).

[31] Lam, J., Enterprise-wide risk management and the role of chief risk officer, $e$-Risk, (2000), 1-5.

[32] Lam, J. and Kawamoto, B.M., Emergence of the Chief Risk Officer, Risk Management, (1997), September: 30-34.

[33] Lang, L. and Stulz, R., Tobin's q, diversification, and firm performance, Journal of Political Economy, 102, (1994)1248-1280.

[34] Liebenberg, A.P and Hoyt, R.E, The Determinants of Enterprise Risk Management: Evidence from the Appointment of Chief Risk Officer, Risk Management and Insurance Review, Vol.6, No.1, (2003), 37-52.

[35] Lintner, J., "The Valuation of Risk Assets and Selection of Risky Investments in 
Stock Portfolios and Capital Budgets", Review of Economics and Statistics, Vol.47, (1965), 13-37.

[36] Lindenberg, E.B. and Ross, A.S, "Tobin's q Ratio and Industrial Organization." Journal of Business, Vol.54, (1981), 1-32.

[37] Lookman, A., "Does Hedging Increase Firm Value? Evidence from Oil and Gas Producing Firms," Working paper, Carnegie Mellon University (2004).

[38] Meulbroek, L.L., Integrated Risk Management for the Firm: A Senior Manager's Guide, Journal of Applied Corporate Finance, Vol.14. (2002) 56-70.

[39] Modiglian, F and Miller, M.H, "The Cost of Capital, Corporation Finance, and the Theory of Investment, The American Economic review 48, (1958), 261 - 297.

[40] Mossin, J., Equilibrium in a Capital Asset Market, Econometrica 34(4), (1966), $768-783$.

[41] Nain, A., "The Strategic Motives for Corporate Risk Management," Working paper, University of Michigan (2004).

[42] Oldfield, G.S and Santomero, M.A (1995). The Place of Risk Management in Financial Institutions, Journal of Banking \& Finance. Vol. 19 (3-4), (1995), 511-27.

[43] Panning, W.H., Managing the Invisible: Measuring Risk, Managing Capital, Maximizing Value (2006) [Online] Available: http://www.ermsymposium.org/2006/pdf ; Accessed on $3^{\text {rd }}$ October 2010

[44] Pratt, J.W., Risk Aversion in the Small and in the Large, Econometrica, Vol. 32, (1964), 122-36.

[45] Servaes, H., The Value of Diversification During the Conglomerate Merger Wave, Journal of Finance, 51, (1996), 1201-25.

[46] Schanfield, A \& Helming, D., 12 Top ERM implementation challenges, Internal Auditor, (2008), 41-44

[47] Sharpe, W.F., "Capital Asset Prices: A Theory of Market Equilibrium Under Conditions of Risk", Journal of Finance, Vol.19, (1964), 425-442.

[48] Smithson, C., Rutter, As and Betty J.S., Does Risk Management Add Value? A Survey of the Evidence, Oklahoma State University (2005)

[49] Standards and Poor's, Ratings Direct (2007), November. Retrieved on 28th January 2009, www.standardandpoors.com/ratingsdirect

[50] Tibachnick, B. G. and Fidell, L. S., Using Multivariate Statistics (3rd edition). Harper Collins; New York (1996).

[51] Tillinghat-Towers, P., Enterprise Risk Management in Insurance Industry Benchmarking Survey Report, (2002) [Online] Available: http://www.towersperrin.com/ ; Accessed on 19 $9^{\text {th }}$ January 2011

[52] Walker, P.L, Shenkir, W.G and Barton, T.L, Enterprise Risk Management: Putting it all together, Institute of Internal Auditors Research Foundation, Altamonte Springs, FL (2002).

[53] Wade, M. and Tomasevic, S. (2006). Theories Used in IS Research - Contingency Theory (2006) [Online] Available: http://www.istheory.yorku.ca/cognitivefittheory.htm; Retrieved on 28th January 2010

[54] Yow, S \& Sherris, M., Enterprise Risk Management, Insurer Value Maximization and Market Frictions, Astin Bulletin, 38(1), (2008), 293-339. 